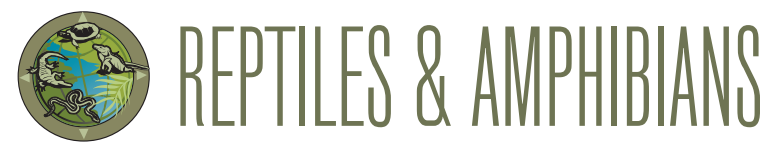

\title{
Predation on a Middle American White-lipped Frog (Leptodactylus fragilis) (Anura:Leptodactylidae) by a Caribbean Ditchfrog (Leptodactylus insularum) (Anura:Leptodactylidae) in Costa Rica
}

Raby Nuñez Escalante and Maikol Marin Sánchez

Sierpe de Osa, Puntarenas, Costa Rica (sierpefrogs@gmail.com [corresponding author], maikolguiacorcovado@gmail.com)

$\mathrm{M}$ any factors influence the feeding habits of amphibians; these include seasonal abundance of prey (Toft 1980), ecological tolerances, and morphological constraints (Duellman and Trueb 1994; Pough et al. 2004). Although dietary specialization is common in dendrobatids (Toft 1995; Caldwell 1996), most amphibians are considered generalist carnivores with diets composed mainly of arthropods and other invertebrates (Duellman and Trueb 1994; Pough et al. 2004). Further, dietary composition is directly influenced by habitat and seasonality (da Rosa et al. 2002).
The Middle American White-lipped Frog (Leptodactylus fragilis) ranges from extreme southern Texas through Mexico and Middle America to northern Colombia and Venezuela. In Costa Rica, it occurs in the Pacific lowlands and locally in the lowlands of the northern Atlantic slopes at elevations from near sea level to about $550 \mathrm{~m}$ (Leenders 2016). The Caribbean Ditch Frog (Leptodactylus insularum) ranges from Costa Rica through Panama into Colombia and Venezuela as well as Trinidad and Tobago at elevations from near sea level to 455 $\mathrm{m}$. These species are sympatric in Costa Rica (Leenders 2016).

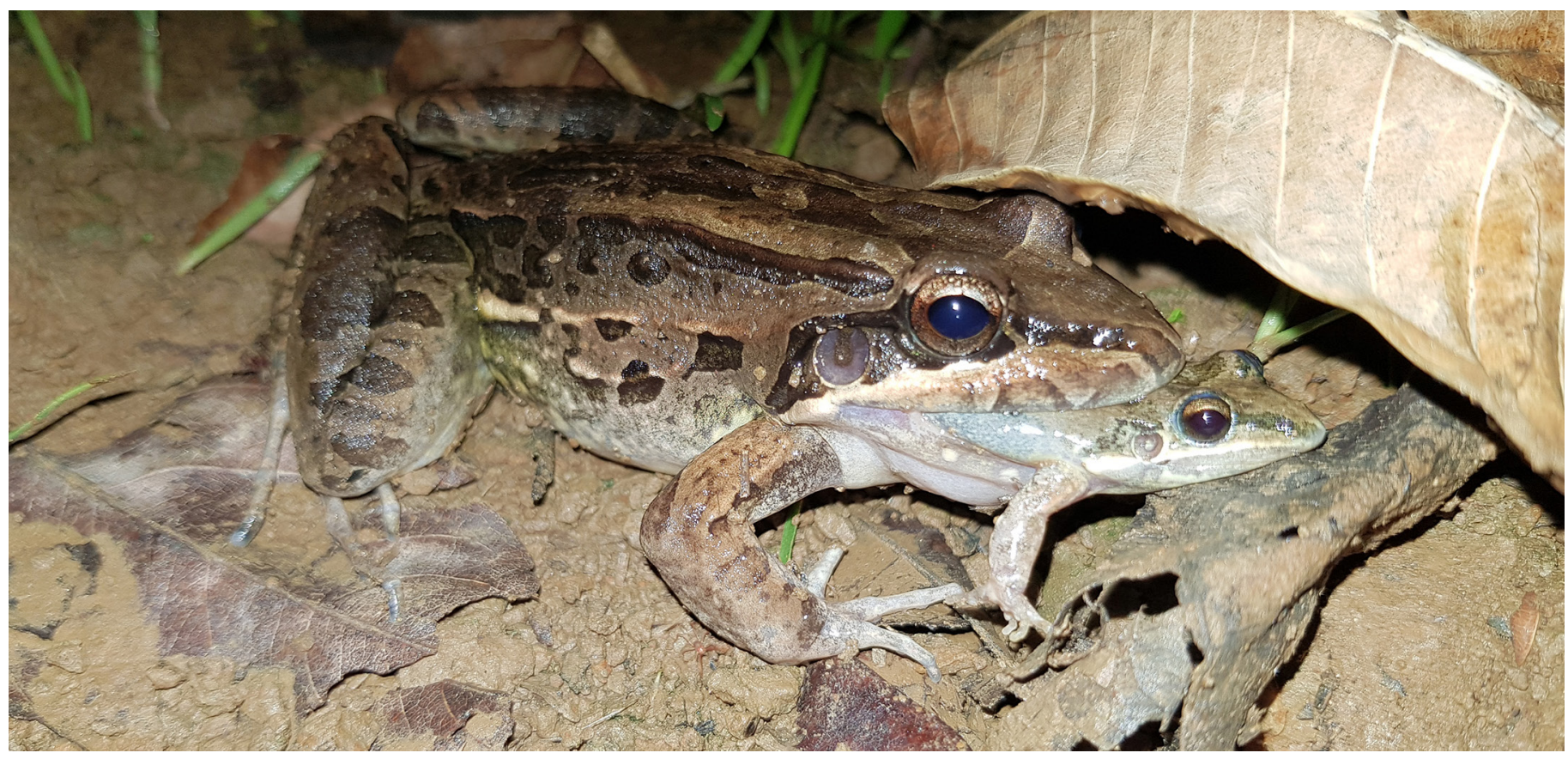

Fig. 1. A Caribbean Ditchfrog (Leptodactylus insularum) preying on a Middle American White-lipped Frog (Leptodactylus fragilis) in La Hacienda, Sierpe de Osa, Costa Rica. Photograph by Maikol Marin Sánchez. 
At 2017 h on 26 April 2020 in la Hacienda $\left(8^{\circ} 50^{\prime} 42.7^{\prime \prime} \mathrm{N}\right.$, $\left.83^{\circ} 25^{\prime} 58.1^{\prime \prime W}\right)$, alerted by a distress call emitted by a Middle American White-lipped Frog, MMS found it being consumed by a Caribbean Ditchfrog (Fig. 1). Ingestion lasted roughly $5 \mathrm{~min}$. To our knowledge, this is the first predation report involving these species.

Frogs that prey on other frogs are not necessarily predators specializing on frogs but may nevertheless feed on them regularly (Toledo et al. 2007). Leptodactylus insularum and $L$. fragilis often breed in the same areas, and syntopy of these two species during reproductive aggregations can promote the predation of the latter smaller species by an opportunistic predator like $L$. insularum.

Other species of Leptodactylus known to prey on frogs and other vertebrates include Savage's Thin-toed Frogs (Leptodactylus savagei) feeding on a Rosenberg's Gladiator Treefrog (Boana rosenbergi) (Kluge 1981) and a Tungara Frog (Engystomops pustulosus) (Ryan et al. 1981); a Northeastern Pepperfrog (Leptodactylus vastus) preying on bats (Leite Filho et al. 2014); and South American Spotted Grassfrogs (Leptodactylus latrans [as L. ocellatus]) preying on an Amazonian White-lipped Frog (Leptodactylus aff. mystaceus) (Silva et al. 2010) and a Leopard Treefrog (Boana pardalis) (Heitor et al. 2012).

\section{Literature Cited}

Caldwell, J.P. 1996. The evolution of myrmecophagy and its correlates in poison frogs (Family Dendrobatidae). Journal of Zoology 240: 75-101. https://doi. org/10.1111/j.1469-7998.1996.tb05487.x.

Da Rosa, I., A. Canavero, R. Maneyro, D.E. Naya, and A. Camargo. 2002. Diet of four sympatric anuran species in a temperate environment. Boletín de la Sociedad de Biología de Uruguay 13: 12-20.

Duellman, W.E. and L. Trueb. 1994. Biology of Amphibians. The Johns Hopkins University Press, Baltimore, Maryland, USA.

Heitor, R.C., V.A. Lacerda, E.T. Silva, M.A. Peixoto, and R.G. Eloi. 2012. Predation of Hypsiboas pardalis (Anura, Hylidae) by the butter frog Leptodactylus cf. latrans (Anura,Leptodactylidae), in municipality of Espera Feliz, State of Minas, southeastern Brazil. Herpetological Notes 5: 23-25.

Kluge, A.G. 1981. The life history, social organization, and parental behavior of Hyla rosenbergi Boulenger, a nest-building gladiator frog. Miscellaneous Publications of the Museum of Zoology, University of Michigan 160: 1-170.

Leenders, T. 2016. Amphibians of Costa Rica: A Field Guide. Zona Tropical Publications, Comstock Publishing Associates, Cornell University Press, Ithaca, New York, USA.

Leite Filho, E., A. Feijóet, and P.A. Rocha 2014. Opportunistic predation on bats trapped in mist nets by Leptodactylus vastus (Anura: Leptodactylidae). Revista Biotemas 27: 205-208. https://doi.org/10.5007/2175-7925.2014v27n3p205.

Pough, F.H., R.M. Andrews, J.E. Cadle, M.L. Crump, A.H. Savitzky, and K.D. Wells. 2004. Herpetology. 3rd ed. Prentice Hall, New York, New York, USA.

Ryan, M.J., M.D. Tuttle, and L.K. Taft. 1981. The costs and benefits of frog chorusing behavior. Behavioral Ecology and Sociobiology 8: 273-278. https://doi. org/10.1007/BF00299526.

Silva E.T., V.D. Fernandes, R.C. Heitor, and V.R. Viana. 2010. Leptodactylus ocellatus (Butter Frog): Prey. Herpetological Bulletin 112: 41-42.

Toft, C.A. 1980. Feeding ecology of thirteen syntopic species of anurans in a seasonal tropical environment. Oecologia 45: 131-141. https://doi.org/10.1007/ BF00346717.

Toft, C.A. 1995. Evolution of diet specialization in poison-dart frogs (Dendrobatidae). Herpetologica 51: 202-216. https://www.jstor.org/stable/3892588.

Toledo, J.F., R.S. Ribiero, and C. Haddad. 2007. Anurans as prey: An exploratory analysis and size relationships between predators and their prey. Journal of Zoology 271: 170-177. DOI: 10.1111/j.1469-7998.2006.00195.x. 